УДК 347.131

DOI https://doi.org/10.32849/2663-5313/2020.2.05

Валерія Джафарова, аспірант кафедри цивільного права та процесу

Харківсъкого начіонального університету внутрішніх справ

\title{
ПРАВОВА ПРИРОДА ТА ОСОБЛИВОСТІ ДЕРЖАВНОЇ РЕЄСТРАЦІЇ РЕЧОВИХ ПРАВ
}

Стаття присвячена виявленню правовстановлюючих юридичнх фактів державної реєстрації. Складність правової природи державної реєстрачії речового права, різні погляди науковиів на щю проблематику свідчать про актуальність иього напряму дослідження. Крім того, попри численні прачі, окремого дослідження правовстановлюючих юридичних фактів у порядку державної реєстрачії речових прав як иивільно-правових фактів не проводилось. Тому метою статті є визначення та характеристика правовстановлюючих юридичних фактів державної реєстрачії речових прав. На підставі проведеного дослідження правовстановлюючих юридичних фактів державної реєстрачії автором доведено, що державна реєстрачія речового права є складним правовим явищем. Вона може розглядатися у вузькому та широкому розумінні. У вузькому сенсі державна реєстрачія є правовстановлюючим фактом у порядку набуття речового права. У широкому розумінні державна реєстрачія речово20 права є: 1) юридичним фактом; 2) прочедурою; 3) юридичним (фактичним) складом. Визначено, що особливість державної реєстрації як юридичного факту полягає в тому, шо стосовно неї існує презумпиія правомірності, завдяки чому і відбувається порядок реєстрації. Згідно з иією презумпиією, будь-які особи, у тому числі державні органи, не можуть нехтувати правами й обов'язками, що виникли внаслідок державної реєстраиї речових прав, або не погоджуватися з фактом реєстрачії. Юридичний (фактичний) склад державної реєстрачії поєднує такі взаємні елементи, як юридичні факти та юридично значуші умови, наслідком чого є набуття речового права. Цей склад охоплює різні за наслідками юридччні факти, серед них правовстановлюючими юридичними фактами можна визнати: звернення заявника щодо реєстрації речового права; формування та реєстрація заяви в базі даних заяв за допомогою програмних засобів ведення Державного реєстру; заява власника об'єкта нерухомого майна про заборону вчинення реєстрачійних дій щодо власного об'єкта нерухомого майна або рішення суду щодо иього.

Ключові слова: правовстановлюючий, юридичний факт, юридичний (фактичний) склад, реєстрація, речові права, право власності, майно, державний реєстратор, юрисдикція.

Постановка проблеми. Державна реєстрація є обов'язковим елементом у порядку набуття речового права. Фактичне виникнення речового права має прив'язку до норм права, які діяли на момент відповідного правочину, у зв'язку з чим в одних випадках державна реєстрація є необхідною, в інших право виникає з моменту виконання певних дій. Внаслідок цього у юриспруденції було сформовано декілька позицій щодо визначення моменту набуття речових прав з урахуванням державної реєстрації. Наявність різних підходів до наведених питань потребуе свого розв'язання, зокрема, шляхом дослідження правовстановлюючих юридичних фактів державної реєстрації речових прав.

Аналіз останніх досліджень. Дослідження правовстановлюючих юридичних фактів державної реєстрації речових прав є комплексним, що потребує застосування здобутків та висновків дослідників різних галузей юридичної науки. Так, питання дер- жавної реєстрації речових прав було предметом наукових робіт А. С. Кечі «Адміністративно-правове регулювання державної реєстрації речових прав на нерухоме майно» (2016р.) [1], Д. С. Спєсівцева «Юридичні факти у механізмах виникнення, переходу та припинення речових прав на нерухомість в Україні» (2017р.) [2], Я. В. Тамаря «Адміністративні процедури 3 державної реєстрації речових прав на нерухоме майно» (2018р.) [3]. Розробленню категорії юридичного факту були присвячені праці дослідників С. С. Алексєєва, В. К. Бабаєва, М. С. Кельмана, В. А. Кройтора, С. О. Комарова, О. В. Петришина, О. Ф. Скакун, Л. І. Спиридонова,Р. О. Халфіної, С. О. Харитонова, Р. Б. Шишки та ін. Попри численні праці, окремого дослідження правовстановлюючих юридичних фактів у порядку державної реєстрації речових прав як цивільно-правових фактів не проводилось. 
Мета статті - визначити та охарактеризувати правовстановлюючі юридичні факти державної реєстрації речових прав. Для досягнення поставленої мети необхідно розв'язати завдання щодо визначення правової природи державної реєстрації речових прав, юридичних фактів та юридичних складів, виявлення правовстановлюючих юридичних фактів у порядку державної реєстрації на підставі аналізу наукових позицій та судової практики.

Виклад основного матеріалу. Досліджуючи правовстановлюючі юридичні факти у порядку державної реєстрації речових прав, перш за все доречно визначитися щодо правової природи державної реєстрації речових прав. Н. В. Майка вказує, що державна реєстрація за своєю природою є правовстановлюючим юридичним фактом [4, с. 44]. I. В. Спасибо-Фатєєва характеризує державну реєстрацію таким чином: 1) реєстрація може розглядатися як фактор публічної достовірності відомостей, поміщених до відповідного реєстру; 2) вона вважається правовстановлюючим фактом; 3) є складником відносин у сфері інформації [5, с. 340].

3 наведеного випливає, що державна реєстрація речових прав може розглядатися у вузькому розумінні як правовстановлюючий юридичний факт, та у широкому розумінні. Для визначення власної позиції щодо цього звернемось до законодавчого тлумачення державної реєстрації речових прав на нерухоме майно та їх обтяжень. Під цим терміном розуміється офіційне визнання і підтвердження державою фактів набуття, зміни або припинення речових прав на нерухоме майно, обтяжень таких прав шляхом внесення відповідних відомостей до Державного реєстру речових прав на нерухоме майно (п. 1 ч. 1 ст. 2 Закону України «Про державну реєстрацію речових прав на нерухоме майно та їх обтяжень») [6]. Отже, законодавець розглядає реєстрацію як публічне визнання факту набуття, зміни або припинення речових прав на нерухоме майно та як процедуру здійснення певних дій щодо публічного визнання речового права певної особи. Для повноти виявлення особливостей державної реєстрації речових прав доречно розглянути це питання 3 точки зору теорії юридичних фактів.

Найбільш поширена позиція щодо юридичних фактів розкриває їх як конкретні життеві обставини, 3 якими юридична норма пов'язує виникнення, зміну чи припинення правових наслідків (правовідносин) [7, с. 163]. Виникнення цивільних суб'єктивних прав та юридичних обов'язків, як і інших прав та обов'язків приватного та публічного характеру, пов'язано з юридичними фактами - конкретними життєвими обставинами, що мають правове значення [8, с. $168 ; 9$, с. 133]. В юридичній літературі справедливо відзначається, що для того, щоб конкретний юридичний факт став підставою виникнення, зміни чи припинення правовідносин, він має бути передбачений нормами законодавства [10, с. 76].

Значення класифікації юридичних фактів полягає в тому, що групування фактів за видами дозволяє краще розпізнавати ix внутрішні (специфічні) властивості, дозволяє з'ясувати, за яких умов та чи інша обставина призводитиме до виникнення правових наслідків, тобто матиме значення юридичного факту [11, с. 45]. С. О. Харитонов влучно зазначає, що юридичні факти можуть поділятися: 1) за ознакою характеру наслідків - на правовстановлюючі, правозмінюючі, правоприпиняючі, юридичні факти, що перешкоджають виникненню або трансформації права; 2) за ознакою галузевої приналежності - на приватноправові; публічноправові; 3) за ознакою пов'язаності правових наслідків з існуванням певного явища або 3 його відсутністю можна розрізняти юридичні факти: позитивні (їх наявність необхідна для виникнення правовідносин); негативні (ї наявність перешкоджає виникненню правовідносин) [12, с. 74]. Юридичні факти також можуть поділятися на правомірні та неправомірні.

Правовстановлюючі юридичні факти це факти, що породжують правовідносини, зокрема суб'єктивні цивільні права та обов'язки. Юридичним фактам притаманна низка характеристик: законність, обгрунтованість, здатність зумовлювати правові наслідки, конкретність, інформативність, оформленість, дієвість [13, с. 57]. Вони завжди індивідуальні та мають наслідки у вигляді виникнення чи трансформації правовідносин. Слід зауважити, що юридичні факти - це завжди дії чи події, з якими норма права пов'язує рух правовідносин.

Рух речових правовідносин виникає з моменту їх державної реєстрації. Так, Законом України «Про державну реєстрацію речових прав на нерухоме майно та їх обтяжень» факт державної реєстрації пов’язаний з моментом набуття речового права та згідно 3 ч. 4 ст. 334 ЦК України права на нерухоме майно, які підлягають державній реєстрації, виникають 3 дня такої реєстрації відповідно до закону; ч. 1 ст. 210 ЦК України встановлено, що правочин, який згідно із законом підлягає державній реєстрації, вважається вчиненим з моменту його державної реєстра- 
ції [14]. Аналогічна позиція простежується у Порядку державної реєстрації (перереєстрації), зняття з обліку автомобілів, автобусів, а також самохідних машин, сконструйованих на шасі автомобілів, мотоциклів усіх типів, марок і моделей, причепів, напівпричепів, мотоколясок, інших прирівняних до них транспортних засобів та мопедів, затвердженому Постановою Кабінету Міністрів України від 7 вересня 1998 р. № 1388. Згідно з ч. 2 п. 7 цієї Постанови забороняється експлуатація транспортних засобів, що не зареєстровані, при цьому сама реєстрація розглядається як процедура [15]. Як зазначається в юридичній літературі, режим експлуатації автомобіля визначає його правовий режим [16, с. 7]. У судовій практиці також склався підхід, за яким строк дії договору, умовами якого передбачено, що відлік строку договору настає 3 моменту його державної реєстрації, починається після набрання ним чинності, а не з моменту його укладення [17]. Виходячи з наведеного, можна констатувати, що державна реєстрація речового права може розглядатися як правовстановлюючий юридичний факт, що має приватноправову природу та позитивний зміст.

Особливість державної реєстрації як юридичного факту полягає в тому, що стосовно неї існує презумпція правомірності, завдяки чому і відбувається порядок реєстрації. Згідно з цією презумпцією, будьякі особи, у тому числі державні органи, не можуть нехтувати правами та обов'язками, що виникли внаслідок державної реєстрації речових прав, або не погоджуватися з фактом реєстрації. Тому факт реєстрації є дійсним до моменту визнання судом його неправомірності. Слід зазначити, що розгляд державної реєстрації речового права як правовстановлюючого юридичного факту є лише одним з аспектів розгляду цієї категорії.

Державна реєстрація може розглядатися і як процедура здійснення дій державного реєстратора як суб'єкта публічної влади. Тому слід розмежовувати юридичний факт державної реєстрації речового права та процедуру державної реєстрації, що становить систему дій державного реєстратора. У першому випадку виникають приватноправові відносини, у другому - публічно-правові. Виникнення різних за правовою природою правовідносин доцільно враховувати як для визначення правового регулювання, так і для встановлення судової юрисдикції, зокрема цивільної або адміністративної. Наприклад, Велика Палата Верховного Суду від 20 березня 2019 р. у справі № $587 / 2110 / 16$-ц постановила, що позов у частині вимог про скасування державної реєстрації оспорюва- ного договору оренди належить розглядати в порядку цивільного, а не адміністративного судочинства [17]. При цьому Велика Палата Верховного Суду дійшла висновку про те, що розгляд позовних вимог особи (яка не була заявником щодо реєстраційних дій) до державного реєстратора про скасування його рішень чи записів у відповідному державному реєстрі стосовно державної реєстрації речових прав на нерухоме майно та їх обтяжень належить до юрисдикції адміністративних судів, оскільки державним реєстратором вчинені істотні порушення процедури реєстрації [18, с. 4]. Отже, у разі виникнення спору щодо захисту цивільних прав та інтересів державна реєстрація буде розглядатися лише як правовстановлюючий юридичний факт у порядку набуття речового права. Вона має прив'язку до майнового права особи, а тому не може розглядатися окремо від цивільних правовідносин. Щодо державної реєстрації як процедури, то це публічні правовідносини, оскільки вона охоплює систему дій уповноваженої особи.

Розглядаючи державну реєстрацію речового права як процедуру, слід зазначити, що вона складається із системно-послідовних дій, що встановлені законом і здійснюються уповноваженою особою на підставі звернення особи. Порядок державної реєстрації охоплює умови, підстави та процедуру реєстрації (п. 1 Порядку державної реєстрації речових прав на нерухоме майно та їх обтяжень, затвердженого Постановою Кабінету Міністрів України від 25 грудня 2015 р. № 1127) [19]. Можливість проведення реєстраційних дій має прив'язку до умов, що визначені законом. Зокрема, умовами реєстрації є сплата адміністративного збору за державну реєстрацію прав, подання заяви та необхідних документів для реєстрації речового права на відповідній об'єкт, установлення факту відсутності відомостей про речові права інших осіб на об'єкт реєстрації тощо. Для кожного об'єкта речових прав або виду речового права можуть встановлюватися різні умови державної реєстрації, що зумовлено особливостями кожного окремого об'єкта. Без встановлення усіх необхідних юридично значущих умов державна реєстрація не здійснюється.

Наявність умов, підстав для здійснення реєстрації та сам факт державної реєстрації не можуть зводитися лише до одного юридичного факту. Тому їх доцільно об’єднувати у більш широке поняття як юридичний (фактичний) склад. Юридичний склад має бути змістовним і достатнім та грунтуватися не лише на наявності юридичних фактів, а й на їх правовому взаємозв’язку 
[20, с. 223]. Не може бути юридичним складом триваючий юридичний факт, що складається із сукупності однорідних обставин, який має правові наслідки (юридичний факт - стан) [21, с. 61]. Слід зазначити, що в юридичній науці існують різні термінологічні підходи щодо визначення юридичного та фактичного складу. Наприклад, М. О. Рожкова вказує, що під юридичним складом слід розуміти сукупність юридичних фактів, у силу норми права необхідну для настання юридичних наслідків [22, с. 16]. М. П. Кучерявенко зазначає, що фактичним складом є сукупність юридичних фактів, які об'єднані у взаємопов'язану та взаємоузгоджену систему елементів, необхідних для виникнення, зміни та припинення правовідносин [23, с. 475]. Аналізуючи різні погляди науковців щодо цього, вважаємо, що поняття юридичного та фактичного складу є тотожними, а отже, у процесі розгляду державної реєстрації прав нами буде використано термін «юридичний (фактичний) склад».

Крім сукупності юридичних фактів, для виникнення юридичного складу необхідні й юридично значущі умови. Елементи юридичного складу чітко встановлюються нормою права та мають взаємозв'язок і єдину спрямованість. Крім того, система юридичного складу не може бути хаотичною - це чітка побудована ієрархія елементів, що спрямована на єдиний результат у вигляді настання правових наслідків. Варто зазначити, що юридичний (фактичний) склад державної реєстрації чітко визначається в законі, що унеможливлює незалежне накопичення фактів і умов. Державна реєстрація речових прав чітко врегульована законом, між іiі процедурними елементами існують логіко-правові зв'язки, та вона складається із таких елементів, як юридичні факти та умови. У зв'язку з цим її доцільно співвідносити з юридичним складом.

Розглядаючи державну реєстрацію речових прав як юридичний склад, необхідно виявити в цій системі правовстановлюючі факти. Встановлення цих фактів є необхідним, оскільки, з одного боку, вони запускають рух підтвердження правомірності набуття речового права, з іншого - є елементом процедури реєстрації. Так, первинним правовстановлюючим фактом державної реєстрації є звернення заявника. Державна реєстрація прав проводиться за заявою заявника шляхом звернення до суб'єкта державної реєстрації прав або нотаріуса, крім випадків, передбачених п. 6 Порядку державної реєстрації речових прав на нерухоме майно та їх обтяжень, затвердженого Постановою Кабінету Міністрів України від 25 грудня 2015 р.
№ 1127 [19]. Отже, звернення особи є юридичним фактом, що призводить до виникнення процедури реєстрації.

Звернення особи, як юридичній факт, має бути правомірним, зокрема, особа повинна мати правоздатність та право на реєстрацію. Іноді виникають ситуації, коли особа не зверталась за реєстрацією. Наприклад, 13 липня 2018 р. Заставнівський районний суд Чернівецької області розглянув справу за зверненням гр. Б., яка заявляла про факт вчинення від іï̈ імені неправомірної реєстрації у вигляді оформлення на їі ім'я права власності на $1 / 3$ частину нежитлової будівлі, автозаправки. Ким саме і з якого саме приводу було здійснено реєстрацію права власності на нежитлову будівлю за нею, їй було невідомо, та вона, у свою чергу, за проведенням такої реєстрації ні до кого не зверталася. При цьому реєстрація проводилась за паспортними даними, які на момент реєстрації були недійсними внаслідок отримання нею нового паспорту із прізвищем чоловіка. Суд, заслухавши усі пояснення сторін та розглянувши докази,+ повністю задовольнив позов [24] Наведена справа підкреслює, що звернення особи за реєстрацією свого речового права $€$ правовстановлюючим фактом державної реєстрації речового права. Його можна охарактеризувати як факт-дію, що повинна мати позитивний зміст і бути правомірною.

Наступним юридичним фактом, що дає можливість проводити процедуру реєстрації речового права, є формування та реєстрація заяви в базі даних заяв за допомогою програмних засобів ведення Державного реєстру. Факт реєстрації та формування заяви є правовстановлюючим, оскільки має наслідки щодо виникнення юридично значущих дій. Так, наслідком такої реєстрації є передача документів у сфері державної реєстрації прав між суб'єктами державної реєстрації прав, їх уповноваженими особами та державними реєстраторами прав на нерухоме майно; відкриття та у випадках, передбачених законом, закриття розділів у Державному реєстрі прав, внесення до розділів або спеціального розділу Державного реєстру прав відомостей про набуття, зміну або припинення речових прав та їх обтяжень, про об'єкти та суб'єктів таких прав тощо (п. 4 Порядку ведення Державного реєстру речових прав на нерухоме майно) [25]. Крім того, з моменту формування та реєстрації заяви в базі даних заяв у заявника виникає суб'єктивне право на захист його законних прав та інтересів щодо правомірності здійснення такого запису, законності використання його персональних даних у Державному реєстрі речових прав на нерухоме майно. 
Прикладом реалізації права на захист у зв'язку із записами в різних розділах Державного реєстру речових прав на нерухоме майно є така судова справа. 06 липня 2018 р. Котовський міськрайонний суд Одеської області задовольнив позов особи, яка просила скасувати запис у Державному реєстрі речових прав на нерухоме майно щодо реєстрації права власності квартири. Свої вимоги позивачка мотивувала тим, що не має можливості розпоряджатися квартирою, оскільки державним реєстратором було здійснено подвійну державну реєстрацію з відкриттям розділів (номери записів про право власності 3606 і 3552, реєстраційний номер об'єкта нерухомого майна 275151000) належної їй квартири. Вказаний факт порушував їі права як власника та фактично позбавляв їі права власності на нерухоме майно без відповідних на це законних підстав [26].

Одним із правовстановлюючих фактів державної реєстрації речових прав можна вважати заяву власника об'єкта нерухомого майна про заборону вчинення реєстраційних дій щодо власного об’єкта нерухомого майна або рішення суду щодо цього. Така заява/ рішення суду одразу реєструються в базі даних заяв. Наслідком цього буде зупинення державної реєстрації прав з обов'язковим посиланням на зареєстроване у базі даних заяв рішення суду чи заяву власника об'єкта нерухомого майна (п. 17 Порядку державної реєстрації речових прав на нерухоме майно та їх обтяжень) [19].

Реєстрація заяви в базі даних заяв щодо речового права не означає, що речове право буде автоматично зареєстровано. Згідно з абзацом першим п. 14 Порядку державної реєстрації речових прав на нерухоме майно та їх обтяжень, «у разі, коли під час розгляду заяви встановлено наявність підстав, передбачених законом для зупинення розгляду заяви, державний реєстратор невідкладно приймає рішення щодо зупинення розгляду заяви» [19]. Зупинення розгляду заяви можливе в разі недотримання умов реєстрації, зокрема, заявник не надав необхідних документів або інформації. У такому разі дія державного реєстратора може розглядатися як правозупиняючий юридичний факт. Якщо заявник не надає необхідних документів, то приймається рішення про відмову в реєстрації. У такому разі виникає правоприпиняючий юридичний факт щодо державної реєстрації речових прав.

Остання стадія процедури реєстрації речового права також містить юридичні факти. Так, за результатом розгляду заяви та документів, поданих для державної реєстрації речових прав, державний реєстратор протягом п'яти робочих днів з дня реєстрації відповідної заяви в Державному реєстрі прав приймає рішення щодо державної реєстрації прав або щодо відмови в такій реєстрації (п. 18 Порядку державної реєстрації речових прав на нерухоме майно та їх обтяжень) [19]. Наведене рішення може розглядатися і як правовстановлюючий юридичний факт, i як правоприпиняючий юридичний факт. У будь-якому разі це є завершальною стадією порядку набуття речового права на відповідний об'єкт. При цьому підставою руху цивільного правовідношення щодо набуття речового права буде не один юридичний факт, а юридичний (фактичний) склад.

Узагальнюючи наведене, слід визначити, що наявність юридичних фактів, різних за характером наслідків у процедурі реєстрації речового права, вказує, що державна реєстрація речового права може розглядатися як юридичний (фактичний) склад. При цьому його природу доречно розглядати як приватноправову, оскільки наслідком реалізації цього юридичного складу буде виникнення речового права. Внутрішні факти-дії у процедурі державної реєстрації матимуть публічно-правовий характер внаслідок того, що вони спрямовані на виникнення дії публічного характеру.

Висновки. На підставі проведеного дослідження правовстановлюючих юридичних фактів державної реєстрації доцільно сформувати такі висновки та пропозиції. Державна реєстрація речового права є складним правовим явищем. Вона може розглядатися у вузькому та широкому розумінні. У вузькому розумінні державна реєстрація $\epsilon$ правовстановлюючим фактом у порядку набуття речового права. У широкому розумінні державна реєстрація речового права $€:$ 1) юридичним фактом; 2) процедурою; $3)$ юридичним (фактичним) складом. Юридичний (фактичний) склад державної реєстрації поєднує такі взаємні елементи, як юридичні факти та юридично значущі умови, наслідком чого є набуття речового права. Цей склад охоплює різні за наслідками юридичні факти, серед них правовстановлюючими юридичними фактами можна визнати: звернення заявника щодо реєстрації речового права; формування та реєстрацію заяви в базі даних заяв за допомогою програмних засобів ведення Державного реєстру; заяву власника об'єкта нерухомого майна про заборону вчинення реєстраційних дій щодо власного об'єкта нерухомого майна або рішення суду щодо цього. Наведені позиції щодо правової природи державної реєстрації, юридичних фактів у процедурі державної реєстрації є лише однією зі спроб розв'язати 
ці питання, а тому цей напрям юридичних розвідок потребує подальшого дослідження у правознавстві.

\section{Список використаних джерел:}

1. Кеча А. С. Адміністративно-правове регулювання державної реєстрації речових прав на нерухоме майно : автореф. дис. ... канд. юрид. наук : 12.00.07. Одеса, 2016. 22 с

2. Спєсівцев Д. С. Юридичні факти у механізмах виникнення, переходу та припинення речових прав на нерухомість в Україні : автореф. дис. ... канд. юрид. наук : 12.00.03. Харків, 2017. 22 с.

3. Тамаря Я. В. Адміністративні процедури 3 державної реєстрації речових прав на нерухоме майно : автореф. дис. ... канд. юрид. наук : 12.00.07. Запоріжжя : Запорізький національний університет, 2018. 15 с

4. Майка Н. В. Реєстрація речових прав на чужу нерухомість як юридичний факт. Юридичний науковий електронний журнал. 2017. № 4. C. $43-45$.

5. Спасибо-Фатеева И. В. Значение государственной регистрации для гражданских правоотношений. Ежегодник украинского права. URL: http://dspace.nlu.edu.ua/bitstream/123456789/ 2260/1/Spasibo-Fateeva_340.pdf. (дата звернення: 12.12.2019).

6. Про державну реєстрацію речових прав на нерухоме майно та їх обтяжень : Закон України від 01.07.2004 № 1952-IV. URL: https:/ / zakon.rada.gov.ua/laws/show / 1952-15 (дата звернення: 12.12.2019).

7. Алексеев С. С. Общая теория права : в 2 т. Москва : Юридическая литература, 1981. Т. 2. 1982. $468 \mathrm{c}$

8. Цивільне право України: Курс лекцій у 6 томах. Т. 1. 2-е вид., виправ. та доп. / за ред. Р. Б. Шишки та В. А. Кройтора. Харків : Еспада, 2008. 680 c.

9. Цивільне право України. Курс лекцій : у 6 томах. Т. 1. Книга I / Р. Б. Шишка, В. А. Кройтор, Я. О. Чапічадзе, М. О. Самойлов ; за ред. Р. Б. Шишки та В. А. Кройтора. Харків : Еспада, 2004. 176 с.

10. Сімейне право : підручник / за заг. ред. проф. В. А. Кройтора та доц. В. Ю. Євко. Харків : ХНУВС, 2016.512 c

11. Цивільне право України : навчальний посібник : у 2 ч. Ч. 1 / за заг. ред. проф. В. А. Кройтора, доцента О. Є. Кухарєва, доцента М. О. Ткалича. Запоріжжя : Гельменевтика, 2016. 384 с.

12.Харитонов Є. О. Деякі питання класифікації юридичних фактів. Актуальні проблеми держави і права. 2008. Вип. 42. С. 73-81.

13. Оборотов Ю. Н. Теория государства и права (прагматический курс). Одесса : Юрид. лит., 2004. 184 c.

14. Цивільний кодекс України : Закон України від 16.01.2003 № 435-IV. URL: http://zakon4.rada. gov.ua/laws/show/435-15.11 (дата звернення: 12.12.2019).

15. Порядок державної реєстрації (перереєстрації), зняття з обліку автомобілів, автобусів, а також самохідних машин, сконструйованих на шасі автомобілів, мотоциклів усіх типів, марок і моделей, причепів, напівпричепів, мотоколясок, інших прирівняних до них транспортних засобів та мопедів : Постанова Кабінету Міністрів України від 07.09.1998 № 1388 URL: https://zakon.rada.gov.ua/laws/show/ 1388-98-\%D0\%BF (дата звернення: 02.12.2019).

16. Самойленко В., Кройтор В. Юридический справочник владельца автомобиля. Харьков : Бизнес Информ, 1996. 528 с.

17. ПостановаВеликоїПалати ВерховногоСуду від 20 березня 2019 р. у справі № 587/2110/16-ц. URL: http://www.reyestr.court.gov.ua/Review/ 80854806 (дата звернення: 18.12.2019).

18. Позачерговий дайджест практики Великої Палати Верховного Суду. Відступ від правової позиції Великої Палати щодо визначення юрисдикції спорів з державним реєстратором / упоряд. д-р юрид. наук О. Р. Кібенко ; відпов. за вип. канд. юрид. наук Р. Ш. Бабанли. Київ, 2018. Вип. 1. 67 с.

19. Порядок державної реєстрації речових прав на нерухоме майно та їх обтяжень : Постанова Кабінету Міністрів України від 25 грудня 2015 p. № 1127. URL: https://zakon.rada.gov.ua/ laws/show/1127-2015-\%D0\%BF\#n366 (дата звернення: 08.12.2019).

20. Сампара Н. Юридичні факти як підстави виникнення субсидіарних цивільно-правових зобов'язань. Актуальні проблеми правознавства. 2017. Випуск 4 (12). С. 223-229.

21. Чернадчук B. Проблеми визначення поняття та класифікації юридичних складів у бюджетному праві. Публічне право. 2014. № 1. C. $60-67$.

22. Рожкова М. А. Юридические факты гражданского и процессуального права: соглашения о защите прав и процессуальные соглашения Москва : Статут, 2009. 332 с

23. Кучерявенко Н. П. Курс налогового права : в 6 т. Харьков : Легас, 2002. Т. 2: Введение в теорию налогового права. 2004. 600 c.

24. Рішення Заставнівського районного суду Чернівецької області. Справа № 716/852/18 від 13.07.2018. URL: http://reyestr.court.gov.ua/ Review/75355510 (дата звернення: 10.12.2019).

25. Порядок ведення Державного реєстру речових прав на нерухоме майно : Постанова Кабінету Міністрів України від 26.10.2011 № 1141. URL: https://zakon.rada.gov.ua/laws/show/ 1141-2011-\%D0\%BF\#n10 (дата звернення: 10.12.2019).

26. Рішення Котовського міськрайонного суду Одеськоїобласті:провадження№ 2/505/1037/2018. Справа № 505/1622/18 від 06.07.2018. URL: http://reyestr.court.gov.ua/Review/75176449 (дата звернення: 10.12.2019). 
The article is focused on revealing constitutive juridical facts of public registration. The complexity of the legal nature of public registration of property right, different views of scholars on this issue indicates the relevance of this area of research. Besides, despite numerous works there was no separate study of constitutive juridical facts in terms of public registration of property rights, as civil facts. Therefore, the purpose of the article is to determine and characterize constitutive juridical facts of public registration of property rights. On the basis of the conducted study of constitutive juridical facts of public registration, the author has proved that public registration of property rights is a complex legal phenomenon. It can be considered in a narrow and broad sense. Public registration in the narrow sense, is a constitutive fact in terms of acquiring property rights. Public registration of property rights in the broad sense, is: 1) a juridical fact; 2) a procedure; 3) a set of facts. It has been determined that the specific feature of public registration, as a juridical fact, is that there is a presumption of eligibility in its respect, which facilitates the registration procedure. Any person, including public authorities, according to this presumption, cannot neglect the rights and obligations that have arisen as a result of public registration of property rights or disagree with the fact of registration. The set of facts of public registration combines such reciprocal elements as juridical facts and legally significant conditions that result in the acquisition of property rights. The set of facts covers various juridical facts in accordance with the consequences, where constitutive juridical facts can be defined: the applicant's petition for registration of a real right; formation and registration of the application in the database of applications by means of software of keeping the State Register; statement of the property owner to prohibit the registration of his own real estate property or a relevant court decision.

Key words: constitutive juridical facts, set of facts, registration, rights in rem, property rights, property, public registrar, jurisdiction. 